\title{
Human insulin and unawareness of hypoglycaemia: need for a large randomised trial
}

\author{
Matthias Egger, George Davey Smith, Arthur Teuscher
}

The synthesis of insulin chemically identical to human insulin was first achieved in $1974 .{ }^{1}$ It was shown to be active in diabetic patients, ${ }^{2}$ but its production costs were prohibitive for general clinical use. Human insulin produced by recombinant DNA technology or by amino acid substitution of pork insulin became available in the late 1970s. ${ }^{3}$ The first trial of the efficacy of human insulin synthesised by recombinant DNA technology in six healthy men was published in $1980 .^{+}$ In comparison with highly purified porcine insulin the study showed a similar efficacy and no severe side effects of human insulin. The authors concluded that their study represented "but the first step in a longer process of investigations of its actions, validation of clinical efficacy in diabetics, and continuing vigilant surveillance for unexpected adverse effects."

The first trial in diabetic patients was published in 1982. It aimed at "ensuring" the safety of biosynthetic human insulin. Though the insulin was shown to be more soluble and absorbed more quickly when subcutaneously injected, diabetologists agreed that human insulin in general has no advantages over highly purified animal insulins. ${ }^{36-8}$ Human preparations nevertheless largely replaced animal insulins within less than a decade, and many patients whose diabetes was well controlled with animal insulin have been transferred to human insulin. More recently, evidence has come forward that human insulin may reduce awareness of hypoglycaemia and thus lead to an increased risk of severe hypoglycaemia. ${ }^{9-13}$ In this article we review the findings relevant to this issue, discuss how this inappropriate situation arose, and what action should now be taken.

\section{Department of \\ Epidemiology and Public Health, University College, London}

Matthias Egger, research

fellow

Department of Public
Health, University of
Glasgow, Glasgow
G12 8RZ
George Davey Smith, senior
lecturer
Department of
Endocrinology and
Diabetes, University of
Berne, Switzerland
Arthur Teuscher, professor
Correspondence to:
Dr Davey Smith.

BMf 1992;305:351-5
TABLE I-Controlled clinical trials comparing human and animal insulins in treating diabetes mellitus

\begin{tabular}{|c|c|c|c|c|c|c|c|}
\hline \multirow[b]{2}{*}{ Study } & \multirow[b]{2}{*}{ No of subjects } & \multirow[b]{2}{*}{$\begin{array}{l}\text { Age (duration of } \\
\text { diabetes) (years) }\end{array}$} & \multirow[b]{2}{*}{$\begin{array}{l}\text { Treatment } \\
\text { period }\end{array}$} & \multicolumn{2}{|c|}{$\mathrm{HbA}_{1}$ concentration $(\%)$} & \multirow[b]{2}{*}{ Severe hypoglycaemia events } & \multirow[b]{2}{*}{$\begin{array}{l}\text { Hypothetical } \\
\text { sample size }\end{array}$} \\
\hline & & & & $\begin{array}{l}\text { Human } \\
\text { insulin }\end{array}$ & $\begin{array}{l}\text { Porcine } \\
\text { insulin }\end{array}$ & & \\
\hline Clark et $a l^{5}$ & 94 & 38 (not given) & 6 Weeks & \multicolumn{2}{|c|}{ Not given ${ }^{\star \star}$} & $\begin{array}{l}3 \text { Patients withdrew because of } \\
\text { hypoglycaemia with human } \\
\text { insulin, none with porcine } \\
\text { insulin or bovine insulin }\end{array}$ & $1983 / 6613$ \\
\hline Mann et $a l^{H}$ & 21 & $12(5)$ & 4 Months & $14 \cdot 4$ & $13 \cdot 8 \dagger$ & $\begin{array}{l}0.8 \text { Episodes/month requiring } \\
\text { treatment with human insulin, } \\
0.3 \text { with porcine insulin }\end{array}$ & $\begin{array}{l}\text { Cannot be } \\
\text { calculated }\end{array}$ \\
\hline Home et al ${ }^{15}$ & 87 & $34(13)$ & 4 Months & $11 \cdot 7$ & $11 \cdot 1 \dagger$ & $\begin{array}{l}4 \text { Physician treated events with } \\
\text { human insulin, } 6 \text { with porcine } \\
\text { insulin }\end{array}$ & $412 / 2059$ \\
\hline Berger et $a l^{\prime \prime}$ & 32 & $37(16)$ & 3 Months & $6 \cdot 8 \ddagger$ & $7 \cdot 2 \ddagger$ & $\begin{array}{l}5 \text { Hypoglycaemic comas with } \\
\text { human insulin, } 4 \text { with porcine } \\
\text { insulin }\end{array}$ & $224 / 751$ \\
\hline Egger et $a l^{13}$ & 44 & $36(16)$ & 6 Weeks & $7 \cdot 5 \ddagger$ & $7 \cdot 4 \ddagger$ & $\begin{array}{l}1 \text { Hypoglycaemic coma with } \\
\text { human insulin, } 2 \text { with porcine } \\
\text { insulin }\end{array}$ & $616 / 1970$ \\
\hline
\end{tabular}

${ }^{\star}$ Number of patients necessary to detect a relative risk of severe hypoglycaemia of $2 / 1 \cdot 5$ with a power of 0.9 at a significance level of 0.05 . $\star \star \mathrm{HbA}_{1}$ concentration not given by species because of treatment-period interaction. $\quad+\mathrm{p}<0.05$.

\section{Randomised clinical trials: little power}

What is the evidence from randomised clinical trials of the risk of severe hypoglycaemia during treatment with human and animal insulins? Table I summarises five randomised double blind crossover trials in insulin treated diabetic patients. ${ }^{5113-15}$ None of them was specifically designed to test whether there is a difference in the risk of severe hypoglycaemia. The main outcome variables were metabolic and immunological variables in the earlier trials and hypoglycaemic symptoms in the more recent ones. Glycaemic control, which is known to be an important risk factor for severe hypoglycaemia, ${ }^{16}$ was significantly better with animal insulin in the early trials. Owing to the small sample sizes and short follow up periods the statistical power of detecting clinically important differences in the incidence of severe hypoglycaemia was limited. Table I gives the number of patients that would need to have been included to make it possible to detect an increase in the risk of severe hypoglycaemia of $100 \%$ and $50 \%$, corresponding to a relative risk of 2.0 and 1.5 respectively. The studies would have needed to have been up to 70 times larger for this purpose. These calculations clearly indicate that only very large relative risks can be excluded on the evidence available from randomised controlled trials.

\section{Responses to induced hypoglycaemia: less pronounced with human insulin?}

Another area of research has focused on counterregulatory hormone responses and symptoms reported during hypoglycaemia induced in a laboratory setting. 
These studies explore the possibility that responses may differ depending on whether hypoglycaemia is induced by human or porcine insulin. Glucagon is the most powerful counterregulatory hormone, acting on hepatic glycogenolysis and gluconeogenesis. Catecholamines produce many, although not all, of the warning symptoms of hypoglycaemia. Adrenaline has a decisive role in glucose recovery in patients with insulin dependent diabetes whose glucagon secretion may be absent. ${ }^{17}$ Hormonal responses have been shown to be reduced in patients with tight glycaemic control ${ }^{18}$ and with a long duration of diabetes ${ }^{19}$ and in patients unaware of hypoglycaemia. ${ }^{20}$

Tables II and III summarise the crossover studies assessing at least one of the key counterregulatory hormones in healthy volunteers ${ }^{21-28}$ and diabetic subjects. ${ }^{28.32}$ There are appreciable differences in the methods used, some investigators relying on intravenous or subcutaneous bolus injections of various doses of insulin to induce hypoglycaemia, others using continuous intravenous infusions. The resulting differences in the rate of glucose fall, in the duration and level of hypoglycaemia, and in insulin concentration makes it problematic to compare them. In diabetic subjects, differences in duration of diabetes and glycaemic control in the patients studied are also important.

The invasive nature of this research restricts it to small numbers of subjects. The high within person variability of the variables assessed, however, makes it unlikely that smaller differences, which could well be clinically relevant, are detected in such studies. This is illustrated by a recent trial comparing catecholamine responses to the same hypoglycaemic stimulus induced in the same five healthy volunteers with the same type of insulin infusion on three different occasions. The adrenaline response varied by $45 \%$ and the noradrenaline response by $19 \%$ between the three occasions..$^{33}$ When hypoglycaemia is induced by subcutaneous injection ${ }^{2428}$ a further source of variability is introduced owing to inconstant insulin absorption rates.

The lack of statistical power of these studies is also evident when hypoglycaemic symptoms are considered In a study of seven patients no systematic differences were found, and it was concluded that the use of human insulin does not carry any risk of altered awareness of hypoglycaemia. ${ }^{32}$ When $95 \%$ confidence intervals were calculated for the findings of this study, however, it became evident that the data are compatible with a difference for neuroglycopenic symptoms ranging from $64 \%$ lower reporting to $53 \%$ higher reporting with human insulin. ${ }^{34}$ Similarly wide confidence intervals were also found for autonomic symptoms.

From review of the studies, it is nevertheless noteworthy that six out of eight studies in healthy volunteers and three out of five in diabetic patients found some differences either in hormonal responses or symptom reporting, or both. These differences always went into the same direction-a more pronounced hormonal response and more symptom reporting with porcine compared with human insulin (Tables II and III). One study, surprisingly first described in an editorial in $1987,{ }^{24}$ stated that there were no significant differences in the mean number of symptoms reported by seven healthy volunteers $(4 \cdot 1$ with Human insulin Actrapid and $7 \cdot 1$ with Porcine insulin Actrapid). However, when the data were presented in more detail in $1990^{35}$ it became evident that this difference was marginally significant $(p=0.05$ with one sided paired $t$ test, our calculation). In another recently published study, which reported significantly higher glucagon and noradrenaline concentrations with porcine insulin at some time points, the authors stated that these differences may have arisen by chance alone because of the large number of statistical tests performed..$^{32}$ This argument is invalid, as by 1991 the hypothesis that porcine insulin may produce a greater response than human insulin was established by previous studies. It is consideration of prior expectations, rather than simple adjustment of the accepted level of significance, which is the appropriate response in this situation. ${ }^{36}$

In summary, our review supports the notion that differences in hormonal responses may exist which tend to be missed due to the limitations of laboratory based studies. ${ }^{37}$ The findings in diabetic patients are compatible with the hypothesis that this may be more important in patients with tight glycaemic control and a long duration of diabetes.

TABLE II -Crossover trials comparing hormonal responses and symptoms in hypoglycaemia induced by human and porcine insulins in healthy subjects

\begin{tabular}{|c|c|c|c|c|c|c|c|}
\hline \multirow[b]{2}{*}{ Study } & \multirow{2}{*}{$\begin{array}{l}\text { No of } \\
\text { subjects/ } \\
\text { episodes }\end{array}$} & \multirow{2}{*}{$\begin{array}{c}\text { Blood } \\
\text { glucose } \\
\text { nadir } \\
(\mathrm{mmol})\end{array}$} & \multirow[b]{2}{*}{ Insulin administration } & \multicolumn{3}{|c|}{ Hormonal response } & \multirow[b]{2}{*}{ Symptoms } \\
\hline & & & & Glucagon & Adrenaline & Noradrenaline & \\
\hline \multirow[t]{2}{*}{ Schlüter ${ }^{21}$} & $6 / 12$ & $<2 \cdot 0$ & Intravenous bolus $0.075 \mathrm{U} / \mathrm{kg}$ & NA & Porcine insulin $>$ human insulin & NS & Porcine insulin $>$ human insulin \\
\hline & $6 / 12$ & $<2 \cdot 0$ & Intravenous bolus $0 \cdot 1 \mathrm{U} / \mathrm{kg}$ & NA & Porcine insulin $>$ human insulin & NS & Porcine insulin $>$ human insulin \\
\hline Rosak $^{22}$ & $8 / 16$ & $<2 \cdot 0$ & Intravenous bolus $0.075 \mathrm{U} / \mathrm{kg}$ & $\mathrm{PI}>\mathrm{HI}^{\star}$ & Porcine insulin $>$ human insulin ${ }^{\star}$ & ND & Porcine insulin $>$ human insulin ${ }^{\star}$ \\
\hline \multirow[t]{2}{*}{ Landgraf-Leurs ${ }^{23}$} & $6 / 12$ & $2 \cdot 0-2 \cdot 5$ & Intravenous bolus $0.075 \mathrm{U} / \mathrm{kg}$ & NS & Porcine insulin $>$ human insulin & NS & Porcine insulin $>$ human insulin ${ }^{\star}$ \\
\hline & $8 / 16$ & $<2 \cdot 0$ & Intravenous bolus $0.12 \mathrm{U} / \mathrm{kg}$ & NS & NS & NS & Porcine insulin $>$ human insulin ${ }^{\star}$ \\
\hline Berger $^{24}$ & $7 / 21$ & $2 \cdot 1$ & Subcutaneous bolus $0.15 \mathrm{U} / \mathrm{kg}$ & NS & NS & NS & Porcine insulin $>$ human insulin $\dagger$ \\
\hline Owens ${ }^{4}$ & $6 / 18$ & $<2 \cdot 0$ & Intravenous bolus $0.1 \mathrm{U} / \mathrm{kg}$ & NS & NS & NA & NA \\
\hline Heine $^{2 n}$ & $8 / 16$ & $2 \cdot 0$ & Intravenous infusion $50 \mathrm{mU} / \mathrm{kg} / \mathrm{h}$ & NS & NS & Porcine insulin $>$ human insulin & Porcine insulin $>$ human insulin \\
\hline $\mathrm{Kern}^{27}$ & $12 / 24$ & $2 \cdot 6$ & Intravenous infusion $90 \mathrm{mU} / \mathrm{kg} / \mathrm{h}$ & NS & NS & NS & NA \\
\hline Haupt $^{2 x}$ & $8 / 24$ & $2 \cdot 0-2 \cdot 5$ & Subcutaneous bolus $0.3 \mathrm{U} / \mathrm{kg}$ & NS & NS & NS & NS \\
\hline
\end{tabular}

${ }^{\star}$ No statistics given. $\quad t p=0.05$, one sided paired test. $\quad \mathrm{NS}=$ difference not significant. ND= no difference evident. NA=not assessed.

All other differences in porcine insulin versus human insulin significant (area under the curve, single time points, symptom scores, or number of symptoms; $p<0 \cdot 05$ ).

TABLE III-Crossover trials comparing hormonal responses and symptoms in hypoglycaemia induced by human and porcine insulins in diabetic patients

\begin{tabular}{|c|c|c|c|c|c|c|c|c|}
\hline \multirow[b]{2}{*}{ Study } & \multirow{2}{*}{$\begin{array}{l}\text { No of subjects/ } \\
\text { episodes }\end{array}$} & \multirow{2}{*}{$\begin{array}{l}\text { Duration of diabetes } \\
\text { (years)/HbA } \\
\text { concentration }(\%)\end{array}$} & \multirow{2}{*}{$\begin{array}{l}\text { Blood glucose nadir } \\
(\mathrm{mmol} / \mathrm{l})\end{array}$} & \multirow{2}{*}{$\begin{array}{l}\text { Insulin } \\
\text { administration }\end{array}$} & \multicolumn{3}{|c|}{ Hormonal response } & \multirow[b]{2}{*}{ Symptoms } \\
\hline & & & & & Glucagon & Adrenaline & Noradrenaline & \\
\hline Fisher $^{24}$ & $\begin{array}{l}8 / 16 \\
8 / 16\end{array}$ & $\begin{array}{l}<5 / 8 \cdot 1 \\
>15 / 7 \cdot 9\end{array}$ & $\begin{array}{l}<2 \cdot 0 \\
<2 \cdot 0\end{array}$ & $\begin{array}{l}\text { Intravenous bolus } \\
0.2 \mathrm{U} / \mathrm{kg}\end{array}$ & $\begin{array}{l}\text { NS } \\
\text { NS }\end{array}$ & $\begin{array}{c}\text { NS } \\
\text { Porcine insulin }> \\
\text { human insulin }\end{array}$ & $\begin{array}{l}\text { NS } \\
\text { NS }\end{array}$ & $\begin{array}{l}\text { NS } \\
\text { NS }\end{array}$ \\
\hline Sjöbom & $8 / 16$ & $11 / 8 \cdot 2^{\star}$ & $2 \cdot 8$ & $\begin{array}{l}\text { Intravenous infusion } \\
\quad 34 \mathrm{mU} / \mathrm{kg} / \mathrm{h}\end{array}$ & NS & NS & $\begin{array}{l}\text { Porcine insulin }> \\
\text { human insulin }\end{array}$ & NA \\
\hline $\begin{array}{l}\text { Bendtson } 31 \\
\text { Haupt }^{2 x}\end{array}$ & $\begin{array}{l}8 / 12 \\
12 / 36\end{array}$ & $\begin{array}{l}6 / 7 \cdot 7^{\star} \\
26 / 9 \cdot 5\end{array}$ & $\begin{array}{l}2 \cdot 1 \\
<2 \cdot 0\end{array}$ & $\begin{array}{l}\text { Intravenous infusion } \\
\text { Subcutaneous bolus } 0.3 \mathrm{U} / \mathrm{kg}\end{array}$ & $\begin{array}{l}\text { NS } \\
\text { NS }\end{array}$ & $\begin{array}{l}\text { NS } \\
\text { NS }\end{array}$ & $\begin{array}{l}\text { NS } \\
\text { NS }\end{array}$ & $\begin{array}{l}\text { NS } \\
\text { NS }\end{array}$ \\
\hline Patrick & $7 / 14$ & $16 / 9 \cdot 6$ & $<2 \cdot 0$ & $\begin{array}{c}\text { Intravenous infusion } \\
150 \mathrm{mU} / \mathrm{kg} / \mathrm{h}\end{array}$ & $\begin{array}{l}\text { Porcine insulin }> \\
\text { human insulin }\end{array}$ & NS & $\begin{array}{l}\text { Porcine insulin }> \\
\text { human insulin }\end{array}$ & NS \\
\hline
\end{tabular}

$\mathrm{NS}=$ difference not significant. $\mathrm{NA}=$ not assessed. Differences porcine insulin versus human insulin significant (area under the curve or single time points, $\mathrm{p}<0 \cdot 05$ ). $\star \mathrm{Hb} \mathrm{blc}$. 


\begin{tabular}{|c|c|c|c|c|}
\hline Study & $\begin{array}{c}\text { No of } \\
\text { patients }\end{array}$ & $\begin{array}{l}\text { Source of } \\
\text { patients }\end{array}$ & $\begin{array}{l}\text { Months since } \\
\text { transfer to } \\
\text { human insulin }\end{array}$ & Main results \\
\hline Berger and Althaus, $1987^{\circ}$ & 39 & Outpatient clinic & Not given & $\begin{array}{l}64 \% \text { Less awareness with human } \\
\text { insulin, } 2 \cdot 5 \% \text { better awareness } \\
\text { with human insulin }\end{array}$ \\
\hline $\begin{array}{l}\text { Teuscher and Berger, } \\
1987^{\prime \prime \prime}\end{array}$ & 176 & Private practice & $1-48$ & $\begin{array}{l}36 \% \text { Symptom change from } \\
\text { autonomic to neuroglycopenic } \\
\text { after transfer }\end{array}$ \\
\hline Redmond, $1988^{38}$ & 158 & $\begin{array}{l}\text { British Diabetes } \\
\text { Association }\end{array}$ & Not given & $\begin{array}{l}24 \% \text { Problems with } \\
\text { hypoglycaemia, } 15 \% \text { less } \\
\text { warning symptoms with human } \\
\text { insulin }\end{array}$ \\
\hline Hepburn et al, $1989^{34}$ & 145 & $\begin{array}{l}\text { Outpatient } \\
\text { clinic }^{\star}\end{array}$ & $1-24$ & $\begin{array}{l}\text { 6\% Less awareness with human } \\
\text { insulin, } 3 \% \text { better awareness } \\
\text { with human insulin }\end{array}$ \\
\hline Duncan et al, $1990^{+1}$ & 120 & $\begin{array}{l}\text { Outpatient } \\
\text { clinic }\end{array}$ & $1-12$ & $\begin{array}{l}10 \% \text { Less autonomic symptoms } \\
\text { with human insulin, } 58 \% \text { less } \\
\text { common hypoglycaemic } \\
\text { reactions }\end{array}$ \\
\hline Stocks, $1991^{+1}$ & 334 & $\begin{array}{l}\text { Outpatient } \\
\text { clinic }\end{array}$ & Not given & $\begin{array}{l}53 \% \text { Symptom change from } \\
\text { autonomic to neuroglycopenic } \\
\text { after transfer }\end{array}$ \\
\hline
\end{tabular}

*44 Patients with reduced awareness of hypoglycaemia before transfer to human insulin were excluded.

Retrospective surveys: less awareness with human insulin in $6 \%$ or $64 \%$ of patients?

Several studies have retrospectively assessed hypoglycaemic symptoms and awareness of hypoglycaemia in patients transferred to human insulin and have found widely differing results (table IV)..$^{9038-41}$ This is not surprising considering the differences in the patient populations studied, the data collection instruments used, and the recall periods involved. Owing to the lack of a control group, selective transfer of patients to human insulin, and retrospective unblinded data collection this approach cannot establish the association, or lack of association, between use of human insulin and unawareness of hypoglycaemia. These observations are nevertheless important because, more than other studies, they reflect the patients' problems with hypoglycaemia and their feeling of safety and wellbeing.

Unawareness of hypoglycaemia may develop with time, irrespective of transfer to human insulin. In an attempt to control for this patients with reduced awareness of hypoglycaemia before transfer to human insulin have been excluded from analysis in one study. ${ }^{39}$ Pre-existing unawareness of hypoglycaemia, however, was ill defined, and the results based on a selected group of patients may underestimate the size of the problem. ${ }^{42}$ One of the surveys also assessed the incidence of severe (physician treated) hypoglycaemic events before and after transfer to human insulin. ${ }^{40}$ The rate of having one event (or more) was $7 / 100$ patient years with animal insulin but $14 / 100$ patient years with human insulin, a difference which approaches significance $\left(p=0.07\right.$ with $\chi^{2}$ test, our calculation). Although such observational data clearly cannot resolve the issue, it is surprising that the authors did not comment on this difference.

\section{Prospective double blind studies: hypoglycaemia symptoms differ}

There have been two randomised double blind trials assessing hypoglycaemic symptoms prospectively during treatment with human and porcine insulins. ${ }^{113}$ Both studies were performed in patients with near normal glycaemic control and a mean duration of diabetes of around 15 years. Analysing 321 episodes recorded by 32 patients, the first study found that hunger and sweating, considered to be "warning" symptoms alerting the patients to incipient hypoglycaemia, were significantly less common initial symptoms during treatment with human insulin.
Conversely, a group of neuroglycopenic symptoms, including lack of concentration and confusion, were more frequent with human insulin. It was concluded that the symptom pattern associated with human insulin could lead to patients failing to take action to avoid developing severe hypoglycaemia. This study, however, was criticised because not all of the hypoglycaemic episodes were confirmed by blood glucose measurements and the results were shown to depend on the (disputed) classification of symptoms into the categories "warning" and "neuroglycopenic". ${ }^{43}$

In the second study, performed by our group, episodes not confirmed by self measurement with fingerstick glucose testing were excluded from analysis. ${ }^{13}$ The results are based on a total of 493 episodes recorded by 44 patients. With human insulin lack of concentration, confusion, and restlessness were significantly more likely to be reported whereas hunger was less likely to occur. Our study therefore was able to confirm the findings of Berger $e t a l^{11}$ in a larger number of confirmed hypoglycaemic episodes. Significant differences were found for individual symptoms, thus making the results independent of the allocation of symptoms into "autonomic" or "neuroglycopenic" groups.

Several findings from our study support the suggestion that treatment with human insulin may be associated with decreased awareness of hypoglycaemia. Less hypoglycaemic values were registered during human insulin treatment, despite similar blood glucose profiles and mean concentrations of glycated haemoglobin during the two treatment periods. This suggests that more episodes went unrecognised with human insulin. Abrupt onset of hypoglycaemia, indicating that there was unawareness of the prodromal phase, was more frequently reported with human insulin. Furthermore, the symptom pattern observed during treatment with human insulin was similar to that found in patients with a history of recurrent severe hypoglycaemia.

Our conclusion, that the symptoms associated with human insulin adversely influence awareness of hypoglycaemia in this manner, was criticised on the grounds that the incidence of severe hypoglycaemic coma did not differ between the two groups ${ }^{44}$ Our trial, however, was not designed to study severe hypoglycaemia,${ }^{45}$ and a far greater sample size would be required for this purpose, as we show in table I. It was also stated that the inclusion of patients with a long history of diabetes might have distorted the results because they already had a modified symptom profile. ${ }^{46}$ The crossover design of the study, with all subjects contributing equally to both treatment arms, renders this argument untenable.

\section{Insights from the diabetes control and complications trial (DCCT)?}

Several studies which had not been designed to examine any potential difference between human and porcine insulins have been exploited for potential insights into this issue. This is best illustrated by the diabetes control and complications trial (DCCT), a large randomised trial studying the effect of intensive insulin treatment compared with conventional treatment on vascular complications in insulin dependent patients. ${ }^{47}$ Insulin species was not randomised, and in many instances was not recorded on the data sheets. Over time the incidence of severe hypoglycaemia decreased by $50 \%$, despite the increasing use of human insulin. On those grounds strong claims were made that there was no concern about safety relating to the use of human insulin. ${ }^{1648}$ The criteria for inclusion into the trial were, however, modified during its course. Patients at high risk for severe hypoglycaemia became 
ineligible for the study. ${ }^{16}$ Patients included at later stages would, therefore, be expected to be at lower risk of hypoglycaemia, and the falling rate of severe hypoglycaemia could be solely due to changes in the eligibility criteria. This trial therefore cannot contribute to considerations of whether there is an increased risk of severe hypoglycaemia in patients transferred to human insulin. Despite this the report of this trial has been uncritically quoted as showing that there is no problem associated with use of human insulin..$^{99.52}$

\section{The bottom line: is there a change in risk of severe hypoglycaemia?}

In the absence of a large randomised controlled trial studies of the risk of severe hypoglycaemia with human and animal insulins have relied on the analysis of retrospective data. In a matched case control study we investigated the period of introduction of human insulin in Switzerland. ${ }^{12}$ Case-control studies have much to recommend them: they require smaller sample sizes than prospective studies, they can often be completed in a shorter time, and they allow retrospective examination of a particular time period, such as that during the introduction of a new drug. Casecontrol studies are, however, susceptible to bias. If patients at high risk for severe hypoglycaemia were more likely to be transferred to human insulin a spurious association between severe hypoglycaemia and use of human insulin could arise. In Switzerland this was generally not the case because most patients were transferred to human insulin simply because their porcine insulins became unavailable. The results indicate that compared with animal insulin human insulin was associated with a threefold increased rate of severe hypoglycaemia. It was argued that our study was biased because of the significantly better blood glucose control in cases compared with controls. ${ }^{+46}$ Glycaemic control was, however, very similar in patients treated with human or animal insulin so the increased risk of hypoglycaemia among diabetic patients using human insulin was not due to this factor. ${ }^{45}$ Good glycaemic control and a previous history of hypoglycaemic coma were also identified as risk factors for severe hypoglycaemia, confirming the results of earlier studies ${ }^{16}$ and increasing confidence that we were identifying true risk factors in our study. Though other factors which were not assessed in the study could, theoretically, account for the results, they would have to be important risk factors for hypoglycaemia and be strongly associated with use of human insulin to explain the raised rate of severe hypoglycaemia associated with use of human insulin. We know of no candidate factors.

To our knowledge this is the only study specifically designed to examine the risk of hypoglycaemia during transition to human insulin. It is unknown to what extent the increased risk of severe hypoglycaemia can be attributed to the fact that many patients were changed to human insulin in their pharmacies, without any medical supervision or information being given. The question, therefore, remains as to whether human insulin itself or unsupervised transfer to human insulin led to this increased rate of severe hypoglycaemia.

Routine mortality and hospital admission data have also been examined in an effort to investigate whether there has been an increase in the risk of severe hypoglycaemia. ${ }^{5354}$ Definite evidence for or against such an increase cannot be obtained by examining time trends from routine data. Changes in the coding rules and in the prevalence of other risk factors may produce spurious associations or obscure real ones. Information on severe hypoglycaemia in diabetic patients is particularly unreliable. Diabetes is often not mentioned on death certificates, while the ICD does not discern between insulin and non-insulin treated diabetes and does not provide a well defined category for diabetes with hypoglycaemia. ${ }^{33}$

\section{Discussion}

Our review indicates that in addition to the slightly faster subcutaneous absorption of human insulin, a different symptom pattern seems to exist in at least one important group of adult insulin-dependent patientsthose with tight glycaemic control and a history of diabetes of several years. The evidence from laboratory based studies of hormonal responses points to differences which, owing to the inherent variability of the variables assessed, cannot consistently be detected by trials lacking statistical power. The pattern of symptoms with human insulin may be of concern because neuroglycopenic symptoms were found to be associated with a history of hypoglycaemic coma. Unfortunately, after the introduction of human insulin the scenario drawn in an early trial ${ }^{4}$ was not followed-no large scale randomised studies were performed and a "continuing vigilant surveillance for unexpected adverse effects" was never established.

The manner by which human insulin was introduced shows several unusual aspects. The decision to produce human insulin on a large scale was taken early on, despite limited clinical experience and a lack of studies showing its long term safety in diabetic patients. Many patients were transferred to human insulin without medical supervision, against the long established rule that treatment in patients whose diabetes is satisfactorily controlled should not be changed merely because newer preparations become available. ${ }^{56}$ This clearly occurred for commercial reasons.

Human insulin generally offers no advantages over highly purified porcine insulins. Even a small increase in the risk of severe hypoglycaemia associated with human insulin would be unacceptable. A randomised clinical trial of adequate size $\mathrm{e}^{57}$ should now be performed to confirm or exclude such an increased risk. The manufacturers who profit from the sale of human insulin should fund this enterprise: this is surely an ethical imperative. Unfortunately they are not keen to do so. ${ }^{58}$

In the mean time, animal insulins must remain available and should be offered in all convenient forms. Regrettably, the mass transfer of patients to human insulin, in a race for market shares, has continued in eastern Europe while cartridges carrying animal insulin remain unavailable for most pen injectors. The lesson to learn is that new therapeutic regimens, even ones apparently little different from previous practice, must be carefully evaluated before widespread introduction, in adequate controlled studies, unless the evidence regarding their advantages is overwhelming. Commercial interests should not be allowed to obstruct the appropriate and ethical process through which new treatments should be introduced.

I Sieber P, Kamber B, Hartmann A, Joehl A, Riniker B, Rittel W, et al. Totalsynthese von Humaninsulin unter gezielter Bildung von Disulfidbindungen. Helv Chim Acta 1974;57:2617-21.

2 Teuscher A. Die biologische Wirkung von vollsynthetischem humanem Insulin bei Patienten mit Diabetes mellitus. Schweiz Med Wochenschr 1979;109:743-7.

3 Home PD, Alberti KGMM. The new insulins: their characteristics and clinical implications. Drugs 1982;24:401-13.

4 Keen H, Glynne A, Pickup JC, Viberti GC, Bilous W, Jarret RJ, et al. Human insulin produced by recombinant DNA technology: safety and hypoglycaemic potency in healthy men. Lancet 1980;ii:398-401.

5 Clark AJL, Adeniyi-Jones RO, Knight G, Leiper JM, Wiles PG, Jones RH, et al. Biosynthetic human insulin in the treatment of diabetes. Lancet 1982;ii:354-7.

6 Parr JH, Abraham RR, Davie MWJ, Dornhorst A, Wynn V. Whither the latest insulins? Lancet 1982;ii:831.

7 Sonnenberg GE, Berger $M$. Human insulin: much ado about one aminoacid? Diabetologia 1983;25:457-9.
Disenterg GE, Berger M. Huma

8 Pickup J. Human insulin. BMF 1986;292:155-7.

9 Berger WG, Althaus BU. Reduced awareness of hypoglycemia after changing from porcine to human insulin in IDDM. Diabetes Care 1987;10:260-1 
10 Teuscher A, Berger WG. Hypoglycaemia unawareness in diabetics transferred to human insulin. Lancet 1987;ii:382-5.

11 Berger W, Keller U, Honegger B, Jaeggi E. Warning symptoms of hypoglycaemia during treatment with human and porcine insulin in diabetes mellitus. Lancet 1989;:1041-4.

12 Egger M, Davey Smith G, Imhoof H, Teuscher A. Risk of severe hypoglycaemia in insulin treated diabetic patients transferred to human insulin a case control study. BMF 1991;303:617-21.

13 Egger M, Davey Smith G, Teuscher AU, Teuscher A. Influence of human insulin on symptoms and awareness of hypoglycaemia: a randomised double blind crossover trial. BMF 1991;303:622-6.

14 Mann NP, Johnston DI, Reeves WG, Murphy MA. Human insulin and porcine insulin in the treatment of diabetic children: comparison of metabolic control and insulin antibody production. BMf 1983;387:1580-2.

15 Home PD, Mann NP, Hutchison NS, Park R, Walford S, Murphy M, et al. A fifteen month double-blind cross-over trial of the efficacy and antigenicity of human and pork insulins. Diabetic Med 1984; i:93-8.

16 DCCT Research Group. Epidemiology of severe hypoglycemia in the Diabetes Control and Complications Trial. Am f Med 1991;90:450-4.

17 Gerich JE, Langlois M, Noacco C, Karam JH, Forsham PH. Lack of glucagon response to hypoglycemia in diabetes: evidence for an intrinsic pancreatic alpha cell defect. Science 1973;182:171-3.

18 Amiel SA, Tamborlane WV, Simonson DC, Sherwin RS. Defective counter regulation after strict glycemic control of insulin-dependent diabetes mellitus. N Engl f Med 1987;316:1376-83.

19 Bolli G, De Feo P, Compagnucci P, Cartechini MG, Angeletti G, Santeusanio $\mathrm{F}$, et al. Abnormal glucose counterregulation in insulin-dependent diabetes mellitus. Interaction of anti-insulin antibodies and impaired glucagon and epinephrine secretion. Diabetes 1983;32:134-41.

20 Heller SR, MacDonald IA, Herbert M, Tattersall RB. Influence of sympathetic nervous system on hypoglycaemic warning symptoms. Lancet 1987;ii: 359-63.

21 Schlüter KJ, Petersen KG, Sontheimer J, Enzmann F, Kerp L. Differen counterregulatory responses to human insulin (recombinant DNA) and purified pork insulin. Diabetes Care 1982;5 (suppl 2):78-81.

22 Rosak C, Althoff P-H, Enzmann F, Schoffling K. Comparative studies in intermediary metabolism and hormonal counter-regulation following human insulin (recombinant DNA) and purified pork insulin in man. Diabetes Car 1982;5(suppl 2):82-9.

23 Landgraf-Leurs MMC, Bruegelmann I, Kammerer S, Lorenz R, Landgraf R. Counterregulatory hormone release after human and porcine insulin in healthy subjects and patients with pituitary disorders. Klin Wochensch 1984;62:659-68.

24 Berger $M$. Human insulin: much ado about hypoglycaemia (un)awareness. Diabetologia 1987;30:829-33.

25 Owens DR, Vora JP, Tronier B, Keller U, Luzio S, Turkes A. Hormonal counterregulatory responses to human (semi-synthetic and recombinant DNA) and porcine insulin induced hypoglycaemia. Diabetes Res 1988;8: $17-20$

26 Heine RJ, van der Heyden EAP, van der Veen EA. Responses to human and porcince insulin in healthy subjects. Lancet 1989;ii:946-9.

27 Kern W, Born J, Kerner W, Fehm HL. Counter-regulatory hormone responses to human and porcine insulin in healthy subjects. Lance 1989;ii:485.

28 Haupt E, Galle $M$, Oerter E. Symptoms of hypoglycaemia and counterregulatory effects with human and animal insulins. In: Federlin $\mathrm{K}, \mathrm{Keen} \mathrm{H}$ Mehnert $\mathrm{H}$, eds. Hypoglycaemia and human insulin. Stuttgart: Georg Thiem Verlag, 1991:119.

29 Fisher BM, Gray CE, Beastall GH, Frier BM. Responses to acute insulin induced hypoglycaemia in diabetic patients: a comparison of short-actin human and porcine insulins. Diabetes Res 1988;8:1-8.

30 Siöbom NC, Lins P-E, Adamson U, Theodorsson E. A comparative study on the hormonal responses to insulin-induced hypoglycaemia using semi- synthetic human insulin and pork insulin in patients with type 1 diabetes mellitus Diabetic Med 1990;7:775-9.

31 Bendtson I, Binder C. Counterregulatory hormonal response to insulin induced hypoglycaemia in insulin-dependent diabetic patients: a comparison of equimolar amounts of porcine and semisynthetic human insulin. $\mathcal{F}$ Interm Med 1991;229:293-6.

32 Patrick AW, Bodmer CW, Tieszen KL, White MC, Williams G. Human insulin and awareness of acute hypoglycaemic symptoms in insulin dependent diabetes. Lancet 1991;338:528-32.

33 Maran A, MacDonald IA, Amiel SA. The euglycemic-hypoglycemic clamp-a reliable tool for the investigation of responses to hypoglycemia [Abstract]? Diabetes 1991;40:544a.

34 Egger M, Davey Smith G, Teuscher A. Hypoglycaemia awareness and human insulin. Lancet 1991;ii:950.

35 Spraul M, Sonnenberg GE, Reck-Linnenberg M, Urbanek C, Berger M. Kein Unterschied in der hormonellen Gegenregulation nach Hypoglykämie durch Schweine-oder Humaninsulin bei stoffwechselgesunden Probanden. durch Schweine-oder Humaninsulin bei stoffwechselges

36 Rothmann KJ. No adjustments are needed for multiple comparisons. Epidemiology 1990;1:43-6.

37 Tattersall RB, MacDonald IA. Human insulin. BMF 1989;299:1339.

38 Redmond S. Changing to human insulin. Balance 1988;Aug/Sept:66-7.

39 Hepburn DA, Eadington DW, Patrick AW, Colledge NR, Frier BM Symptomatic awareness of hypoglycaemia: does it change on transfer from animal to human insulin? Diabetic Med 1989;6:586-90.

40 Duncan C, Campbell IW, McBain AM, Jones IG. Hypoglycaemia survey in insulin-dependent diabetic population at time of change from beef to human insulin. Practical Diabetes 1990;7:18-9.

41 Stocks AE. Human insulin. Med f Aust 1991;154:295-6.

42 Egger M, Teuscher A. Symptomatic awareness of hypoglycaemia: does it change on transfer from animal to human insulin? Diabetic Med 1990;7:269.

43 Hepburn DA, Frier BM. Hypoglycaemic unawareness and human insulin. Lancet 1989; $1: 1394$.

44 Patrick AW, Williams G. Human insulin. BMf 1991;303:1266.

45 Egger M, Davey Smith G, Teuscher A. Human insulin. BMJ 1991;303: 1267-8.

46 Frier BM, MacLeod KM, Hepburn DA. Human insulin. BMF 1991;303 1266-7.

47 DCCT Research Group. The diabetes control and complications trial (DCCT) Design and methodologic considerations for the feasibility phase. Diabetes 1986;35:530-45.

48 Gorden PH. Human insulin and hypoglycemia. N Engl f Med 1990;322: $1007-8$

49 Anon. Hypoglycaemia and diabetes control. Lancet 1991;338:853-5.

50 Orchard TJ, Maser RE, Becker DJ, Donnan JS, Drash AL. Human insulin use and hypoglycemia: insights from the Pittsburgh epidemiology of diabetes complications study. Diabetic Med 1991;8:469-74.

51 Tattersall RB, Gill GV. Unexplained deaths of type 1 diabetes under age 50 Diabetic Med 1991;8:49-58.

$52 \mathrm{Karem} \mathrm{JH}$. Hormonal responses to human and pork insulin. Clinical Diabete 1991;Nov/Dec:94-5.

53 Stephenson J, Fuller J. Hypoglycaemia as a cause of death in human insulin era. Lancet 1990;335:661.

54 Heine RJ, van der Veen EA. Human insulin and hypoglycaemia. Lance $1990 ; \mathrm{i}: 62$.

55 Teuscher A, Diem P. Do fully synthetic and genetically synthesised human insulins differ? Lancet 1980;ii: 1186 .

56 Keen H, Jarrett J. Management of diabetes. Medicine International 1981;1 330-3.

57 Egger M, Teuscher A, Berger W. Hypoglycaemia (un)awareness: human vs animal insulin. Diabetologia 1988;31:453-4.

58 No funding for definitive insulin study. Scrip 1992;7 February:22.

\title{
Human insulin and hypoglycaemia: burning issue or hot air?
}

\author{
Gareth Williams, Alan W Patrick
}

Does the use of human sequence insulin prevent diabetic patients from perceiving hypoglycaemic symptoms, and does it increase the risk of severe hypoglycaemia?

These questions were first raised five years $\mathrm{ago}^{1}$ and continue to trouble those involved with diabetes. The issue is difficult to resolve because the suspected adverse effects of human insulin - that is, reduced awareness of hypoglycaemia and increased rate of severe episodes - are inextricably woven into the fabric of insulin treatment. Despite many patients' claims the ability to estimate the prevailing blood glucose concentration is notoriously poor ${ }^{2}$; for example, even educated and motivated patients who took part in a recent study of hypoglycaemia wrongly judged themselves to be hypoglycaemic in a quarter of episodes. ${ }^{3}$ Perception of hypoglycaemia can be dulled by many factors, including alcohol and various drugs. Moreover, for reasons which remain obscure, many patients with longstanding diabetes lose awareness of the onset of hypoglycaemia and may rapidly develop neuro- glycopenic features (for example, confusion, aggression, and coma) before any recognisable sympathetically mediated symptoms such as sweating and tremor. This occurs irrespective of the insulin species used and was well recognised long before the advent of human insulin. ${ }^{4}$

Hypoglycaemia is an inevitable consequence of the narrow therapeutic ratio of insulin and is a common complication of treatment of diabetes: each year one in seven insulin dependent diabetic patients will have a hypoglycaemic episode severe enough to cause unconsciousness or require help from others. A specific effect of human insulin is all the harder to detect against this noisy background because its introduction during the 1980s generally coincided with greater efforts to tighten glycaemic control by intensifying insulin treatment, which itself may make hypoglycaemia more frequent. ${ }^{6}$ This important confounding factor, also not related to insulin species, is highlighted by the $68 \%$ increase in the frequency of severe hypoglycaemia observed in diabetic children in Bern

Dr Williams. 